\title{
Trade Openness and Economic Growth in China and India in Comparative Perspective: An Exploratory Study
}

\author{
Falendra Kumar Sudan \\ Department of Economics, University of Jammu, India \\ Email: fk_sud@rediffmail.com
}

Received: 10 August 2021; Revised: 13 January 2022; Accepted: 11 February 2022

\begin{abstract}
China's economic success has been attributed to export-led growth, while India has used export-led growth and domestic demand-led growth simultaneously. Therefore, both economies can learn from each success in trade performance vis-a-vis economic growth. The paper intends to analyze trade openness and economic growth performance in comparative perspective of China and India and draws policy implications using data triangulation methods. The study reveals that Trade openness ratio stood at $35.4 \%$ and $31.9 \%$ respectively in China and India in 2018, which reflects narrowing down in trade-GDP ratio in two economies. China recorded simple exports-GDP ratio at $20.5 \%$ and $42.34 \%$ respectively in 2000 and 2010 compared to India's corresponding figures at $9.6 \%$ and $15.1 \%$ respectively, reflecting much more integration of China into global trade compared to India. Export-GDP ratios have steadily increased in both countries since 1991, but declined in 2008 due to effects of the global recession and stood at $18.3 \%$ and $12.5 \%$ respectively in China and India in 2018. Over the period, China has emerged as India's largest trading partner, but bilateral trade gap of India is also increasing with its overall trade gap with rest of the world, which contributes to overall trade imbalance of India and poses a policy challenge to sustain trade between two countries along with narrowing the existing bilateral trade gap, which can be addressed effectively by India's technology-intensive exports to China. Both countries are required to remove existing trade barriers and constraints to reap full trade potential focusing on customs rules and procedures, standards, certification and regulatory practices, non-tariff barriers, and rules of origin. Mutual consensus on customs valuation and guidelines to facilitate uniform documentation across ports are needed to increase China-India trade. Despite high degree of openness, both countries experienced a small deceleration in growth in recent years. Therefore, free trade and sustained reforms are the best options for China and India to return to sustainable growth rates.
\end{abstract}

Keywords: trade openness, economic growth, China, India, policy implications

JEL Codes: F10, F13, F41, F43

\section{Introduction}

Before the 1970s, many developing economies pursued import substitution due to apprehension of foreign dominance, declining terms of trade and support to domestic manufacturing. However, small size of domestic markets and high tariffs resulted in inefficient manufacturing, less employment generation and low economic growth (Balassa,

Copyright (C2022 Falendra Kumar Sudan

DOI: https://doi.org/10.37256/redr.3120221091

This is an open-access article distributed under a CC BY license

(Creative Commons Attribution 4.0 International License)

https://creativecommons.org/licenses/by/4.0/ 
1978; Bhagwati, 1978). In the 1980s, the linkages between trade policy and economic growth received renewed attention. The relationship between trade openness and economic growth has been widely studied (Dollar, 1992; WhaLee, 1993; Sachs \& Warner, 1995; Harrison, 1996; Jin, 2000; Greenaway et. al., 2002). Substantial expansion of exports led to improved economic performance (Krueger, 1985). Increase in domestic demand [non-export Gross Domestic Product (GDP)] also surged with rapid expansion in exports (Greenaway \& Sapsford, 1994). This phenomenon is termed as Export-Led Growth Hypothesis (ELGH) (Balassa, 1985; Bhagwati, 1988; Edwards, 1998; Shirazi \& Manap, 2005). The ELGH suggests that increase in export is one of the key determinants of economic growth. A dynamic export sector (Romer, 1986) and trade openness lead to technological development (Barro \& Sala-i-Martin, 1995; Edwards, 1998). Trade openness caused employment generation, higher productivity of human resources, a better distribution of scarce resources, higher external income, more foreign investment, and greater total factor productivity (World Bank, 1993).

The ELGH has been widely analyzed (Jung \& Marshall, 1985; Greenaway \& Sapsford, 1994; Riezman et al., 1996; Dhananjayan \& Devi, 1997; Shan \& Sun, 1998). Edwards (1998) studied the impact of trade openness on productivity. Numerous studies investigated the legitimacy of the ELGH. Most earlier empirical studies supported the ELGH (Balassa, 1985; Bhagwati, 1988; Feder, 1982; Grossman \& Helpman, 1991; Sala-i-Martin, 1996; Howitt \& Aghion, 1998; Salai-Martin et al., 2004), while several studies discarded it (Papanek, 1973; Kormendi \& Meguire, 1985; Gonçlaves \& Richtering, 1987; Mbaku, 1989; De Gregorio, 1992; Sprout \& Weaver, 1993; Greenaway \& Sapsford, 1994; Amirkhalkhali \& Dar, 1995; Yaghmaian \& Ghorashi, 1995; Burney, 1996). Some studies reported variations in exports and growth outcomes due to country-specific characteristics (Awokuse, 2005; Dodaro, 1993; Riezman et al., 1996; Pomponio, 1996). The extant studies on India also support positive correlation between exports and growth (Mallick, 1994; Sampath \& Anwar, 2000; Nidugala, 2001; Love \& Chandra, 2004; Sharma \& Panagiotidis, 2004; Kaushik \& Klein, 2008; Ray, 2011). In recent decades, China's economic performance holds the case of trade openness (Findlay \& Watson, 1996). However, studies on links between trade openness and growth in comparative perspective of China and India are virtually absent, which is intended to analyze in the present study.

\section{Objectives and methodology}

The self-impelled domestic economic growth causes high efficiency and increases exports (Vernon, 1966). There exists two-way relationship between exports and growth, the first export growth causes high competition and generates early growth momentum and two, the greater manufacturing efficiency encourages further increase in export expansion (Balassa, 1985; Bhagwati, 1988). The ELGH supports the ideas of development of international and domestic competitive markets, the adoption of new technology, increase in productivity, greater trade liberalization and economies of scale, higher exports, more output and rapid employment (World Bank, 1993). ELGH received an extensive support from policy makers in developing economies (Tyler, 1981; Balassa, 1985), while import substitution led to poor growth performance (Balassa, 1980; Barro \& Sala-i-Martin, 1995), which caused the end of initial phase of this strategy and encouraged export-led orientation for economic recovery in developing countries (Bruton, 1989). Against the above backdrop, the present study aims to analyze the role of trade in exports and validate the ELGH for China and India in comparative perspective using data triangulation method.

The study has used data triangulation method to overcome the possible bias in use of single-data source and to increase the validity and reliability of the research outcomes. Triangulation is widely used in the qualitative research. Triangulation refers to the method that facilitates to improve the reliability and legitimacy of research outcomes (Noble \& Heale, 2019). Data triangulation is one of the methods to improve the validity of research (Denzin, 1978). Data triangulation refers to collection and use of numerous data sources over time, space and person (Korstjens et al., 2018) to explore the data normalcy and enhance research findings and extant knowledge (Bans-Akutey \& Tiimub, 2021). The most recent data required for the present analysis has been utilized from publications of the Asian Development Bank (ADB), International Monetary Fund (IMF), International Trade Centre (ITC), the Organization for Economic Cooperation and Development (OECD), the World Bank, etc. Data triangulation has been used due to its merit of trendiest and the easiest to put into practice. Data triangulation facilitates in cross-checking of the consistency and accuracy of data entries from diverse sources. A careful review of data collected from different sources has been 
accomplished to arrive at more accurate qualitative results.

\section{Review of literature}

Earlier research analyzed economic growth in terms of export-led orientation (Emery, 1967; Emery, 1968; Syron \& Walsh, 1968; Serven, 1968; Kravis, 1970; Michaely, 1977; Heller \& Porter, 1978; Bhagwati, 1978; Krueger, 1978). This was followed by an examination of connection between export and output growth (Balassa, 1978; Balassa, 1985; Tyler, 1981; Feder, 1983; Kavoussi, 1984; Ram, 1985; Ram, 1987; Moschos, 1989). Various studies substantiated a strong relationship between trade openness and economic growth (Grossman \& Helpman, 1991; Sala-i-Martin, 1996; Howitt \& Aghion, 1998; Sala-i-Martin et al., 2004). The trade openness significantly impacts growth performance (Dollar, 1992; Sala-i-Martin, 1996; Dollar \& Kraay, 2004; Wacziarg \& Welch, 2008; Chang \& Mendy, 2012; Jouini, 2015; Chenery \& Strout, 1966; Balassa, 1978; Feder, 1983; Al-Yousif, 1997; Vohra, 2001; Kalaitzi \& Chamberlain, 2020). Some studies found a negative relationship between trade openness and economic growth (Levine \& Renelt, 1992; Rodriguez \& Rodrik, 2000; Yanikkaya, 2003; Herzer et al., 2006; Kalaitzi \& Cleeve, 2018).

A plethora of studies analyzed relationship between trade and growth performance in developed and developing countries (Baliamoune-Lutz, 2011; Bhagwati \& Srinivasan, 1975; Keesing, 1967; Marjit \& Ray, 2017; Ncube \& Cheteni, 2015; Sun et al., 2021a). The ELGH caused better economic performance in developed countries (Afxentiou \& Serletis, 1991; Henriques \& Sadorsky, 1996; Boltho, 1996). However, this was not the case in developing countries (Catão, 1998). Some studies found substantial linkage between export growth and economic growth (Ram, 1987; Balassa, 1980) specifically after attaining a positive level of economic development (Syron \& Walsh, 1968; Kravis, 1970; Michaely, 1977; Heller \& Porter, 1978; Balassa, 1978).

A strong relationship between export performance and growth exists (Islam, 1998) in the long term (Chow, 1987; Sephton, 1989). Some recent studies authenticates ELG hypothesis (Kalaitzi \& Cleeve, 2018; Kalaitzi \& Chamberlain, 2020). Various studies have not supported ELGH (Papanek, 1973; Kormendi \& Meguire, 1985; Helleiner, 1986; Gonçalves \& Richtering, 1987; Mbaku, 1989; De Gregorio, 1992; Sprout \& Weaver, 1993; Amirkhalkhali \& Dar, 1995; Yaghmaian \& Ghorashi, 1995; Burney, 1996). However, Al-Yousif (1997) rejected the applicability of ELGH in the long term. Trade openness impacts economic growth in the long-run up to a certain level and then declines (Zahonogo, 2016).

Various studies analyzed the causality between exports and economic performance (Yanikkaya, 2003; Shirazi \& Manap, 2004; Siliverstovs \& Herzer, 2006; Gbaiye et al., 2013; Ahmad et al., 2018). Abu Al-Foul (2004) found a unidirectional causal linkage between export growth and economic performance. Some studies found a bi-directional links between export growth and economic progress (Panas \& Vamvoukas, 2002; Narayan et al., 2007; Elbeydi et al., 2010; Mishra, 2011; Kalaitzi \& Cleeve, 2018; Dinç \& Gökmen, 2019; Sun et al., 2021b). However, Kwan and Cotsomitis (1991), El-Elbeydi et al. (2010) and Tang (2006) found no causal relationship between export growth and economic performance. El-Elbeydi et al. (2010) reported the long-term relationship between export growth and economic performance. Trade openness impacts economic growth in the long-run up to a certain level and then declines (Zahonogo, 2016).

Some country-specific studies evaluated the relationship between export growth and economic performance (Khan \& Saqib, 1993; Serletis, 1992; Henriques \& Sadorsky, 1996; Al-Yousif, 1997; Begum \& Shamsuddin, 1998) and found positive correlation between exports and growth in India (Mallick, 1994; Sampath \& Anwar, 2000; Nidugala, 2001; Love \& Chandra, 2004; Sharma \& Panagiotidis, 2004; Kaushik \& Klein, 2008; Ray, 2011) and China in recent decades (Findlay \& Watson, 1996). Most of the extant literature reveals a direct relationship between trade openness and economic growth. To the best of my knowledge, none of the existing studies have analyzed the linkages between trade openness and economic growth in the comparative perspective of China and India. The present study aims to fill the gap in existing studies by confining to two Asian giants viz. China and India on the phenomenon under study. 


\section{Results and discussions}

In 1978, China's trade openness was estimated at 13.7\% compared to India's trade openness of 12.7\%. In 1987, India's trade openness was nearly $43 \%$ of China's trade openness. With rapid trade liberalization, India's trade openness has surged to $49.7 \%$ and reached about $90 \%$ of China's trade openness ratio in 2008. Compared to the 1980s, China has improved her openness ratio to $62.2 \%$ in 2005, but declined to 55\% of the GDP in 2008 due to Global Financial Crisis (GFC) (World Bank, 2011). Table 1 reveals that external trade balance had surged in China from 2000 to 2015 and then declined in 2018; however, it remained negative in India over the period. Trade openness ratio stood at $35.4 \%$ and $31.9 \%$ respectively in China and India in 2018, which reflects narrowing down in trade-GDP ratio in two economies. China recorded simple exports-GDP ratio at $20.5 \%$ and $42.34 \%$ respectively in 2000 and 2010 compared to India's corresponding figures at $9.6 \%$ and $15.1 \%$ respectively, reflecting much more integration of China into global trade compared to India. Export-GDP ratios have steadily increased in both countries since 1991, but declined in 2008 due to effects of the global recession and stood at $18.3 \%$ and $12.5 \%$ respectively in China and India in 2018.

Table 1. Growth of GDP and external trade in China and India (US\$ billion)

\begin{tabular}{|c|c|c|c|c|c|c|c|c|}
\hline \multirow{3}{*}{ Year } & \multicolumn{4}{|c|}{ China } & \multicolumn{4}{|c|}{ India } \\
\hline & \multirow{2}{*}{ GDP } & \multicolumn{3}{|c|}{ External trade } & \multirow{2}{*}{ GDP } & \multicolumn{3}{|c|}{ External trade } \\
\hline & & Export & Import & Trade balance & & Export & Import & Trade balance \\
\hline 2000 & 1211.3 & 249.2 & 225.1 & 24.1 & 484.5 & 46.6 & 52.83 & -273.0 \\
\hline 2005 & 2285.9 & 762.0 & 660.0 & 102.0 & 837.5 & 104.9 & 151.92 & -2039.9 \\
\hline 2010 & 6087.2 & 1577.8 & 1396.2 & 181.5 & 1702.3 & 257.7 & 379.53 & -5405.5 \\
\hline 2015 & 11015.5 & 2273.5 & 1679.6 & 593.9 & 2146.7 & 270.3 & 392.17 & -7730.2 \\
\hline 2018 & 13608.1 & 2487.4 & 2135.6 & 351.8 & 2779.7 & 347.1 & 540.56 & -12837.9 \\
\hline \multicolumn{9}{|c|}{ CAGR (\%) } \\
\hline $2000-2005$ & 13.5 & 25.0 & 24.0 & 33.4 & 11.5 & 17.6 & 23.5 & 49.5 \\
\hline $2005-2010$ & 21.6 & 15.6 & 16.1 & 12.2 & 15.2 & 19.7 & 20.1 & 21.5 \\
\hline $2010-2015$ & 12.6 & 7.6 & 3.7 & 26.7 & 4.7 & 0.9 & 0.6 & 7.4 \\
\hline $2015-2018$ & 7.3 & 3.1 & 8.3 & -16.0 & 8.9 & 8.7 & 11.3 & 18.4 \\
\hline $2000-2018$ & 14.4 & 13.6 & 13.3 & 16.0 & 10.2 & 11.8 & 13.8 & 23.8 \\
\hline
\end{tabular}

Source: Compiled from ADB (2020a, 2020b), IMF (2020), OECD (2018), WEF (2020), World Bank (2020a, 2020b, 2020c), and WTO (2020) Note: Data for India converted from INR to US\$

Table 1 also reveals that during 2000 to 2005, China's exports and imports have surged at the Compound Average Growth Rate (CAGR) of 25\% and 24\%, respectively, which fell subsequently during 2005 to 2010 by $15.6 \%$ and $16.1 \%$ respectively due to impact of GFC. In 2010, China became the world's largest exporter of commodities. China's exports and imports have declined further between 2010 and 2015, with export and import growth averaging 7.6\% and 3.7\% respectively and thereafter China's trade flows have declined sharply between 2015 and 2018. Thus, China's foreign trade volume remained significantly higher compared to India and its share in global exports has been consistently higher than its imports in recent decades, whereas reverse is true for India.

Table 2 reveals that global exports balance for China surged more than twenty-six times from US\$22.5 billion in 2001 to US\$ 600.2 billion in 2015 and declined to US\$ 429.6 billion in 2019, whereas India recorded a negative world trade balance over the period. India's merchandise exports have surged from 2001 to 2019, which led to significant increase in merchandise trade to GDP ratio and world merchandise exports. However, China's merchandise exports have 
surged more rapidly and stood at 6-7 times higher than India during the same period, while an increase in merchandise imports in China remained more than 4-times higher than India for most of the period, which clearly reflects stronger performance of China's trade compared to India. India had experienced negative trade balance compared to positive trade balance in merchandise products in China from 2001 to 2019 due to stronger manufacturing growth in China than India, while China's recorded negative trade balance compared to positive trade balance in services in India due to stronger performance of service sector in India compared to China.

In China and India, both the exports to and imports from the world have increased significantly, however, multipletimes higher in China than India (WTO, 2018). China's trade flows recovered significantly in 2017 due to increase in commodity imports driven mainly by solid domestic demand (World Bank, 2017). In early 2018, China's current account experienced a deficit for the first time since the second half of the 2001, which is attributed to strong imports, mainly of machinery and equipment (World Bank, 2018).

Table 2. Trade balance, exports and imports in China and India

\begin{tabular}{|c|c|c|c|c|c|c|c|c|c|c|c|c|}
\hline \multirow{3}{*}{ Year } & \multicolumn{6}{|c|}{ China (US\$ billion) } & \multicolumn{6}{|c|}{ India (US\$ billion) } \\
\hline & \multicolumn{3}{|c|}{ Trade (products) } & \multicolumn{3}{|c|}{ Trade (services) } & \multicolumn{3}{|c|}{ Trade (products) } & \multicolumn{3}{|c|}{ Trade (services) } \\
\hline & Balance & Export & Import & Balance & Export & Import & Balance & Export & Import & Balance & Export & Import \\
\hline 2001 & 22.5 & 266.1 & 243.5 & n.a & n.a & n.a & -6.8 & 43.8 & 50.6 & n.a & n.a & n.a \\
\hline 2005 & 102.0 & 761.9 & 659.9 & -5.5 & 78.4 & 83.9 & -40.5 & 100.3 & 140.9 & 18.1 & 106.0 & 87.9 \\
\hline 2010 & 181.7 & 1577.7 & 1396.0 & -15.0 & 178.3 & 193.4 & -129.6 & 220.4 & 350.0 & 2.1 & 117.0 & 114.9 \\
\hline 2015 & 600.2 & 2281.8 & 1681.6 & -216.9 & 218.6 & 435.5 & -126.9 & 263.9 & 390.8 & 32.7 & 156.3 & 123.5 \\
\hline 2019 & 429.6 & 2498.5 & 2068.9 & -258.2 & 266.8 & 525.0 & -155.6 & 323.2 & 478.9 & 28.5 & 205.1 & 176.6 \\
\hline \multicolumn{13}{|c|}{ CAGR (\%) } \\
\hline $2001-2005$ & 45.9 & 30.1 & 28.3 & n.a & n.a & n.a & 56.2 & 23.0 & 29.2 & n.a & n.a & n.a \\
\hline $2005-2010$ & 12.2 & 15.6 & 16.1 & 22.2 & 17.8 & 18.2 & 26.2 & 17.0 & 19.9 & -65.9 & 5.1 & 14.3 \\
\hline $2010-2015$ & 26.9 & 7.6 & 3.8 & 70.6 & 4.1 & 17.6 & -0.4 & 3.7 & 2.2 & 73.1 & 5.9 & 1.4 \\
\hline 2015-2019 & -8.0 & 2.3 & 5.3 & 5.9 & 6.8 & 6.4 & 5.2 & 5.2 & 5.2 & -4.5 & 9.5 & 12.6 \\
\hline $2001-2019$ & 17.8 & 13.2 & 12.6 & 34.4 & 9.8 & 15.1 & 19.0 & 11.7 & 13.3 & 4.6 & 6.8 & 7.2 \\
\hline
\end{tabular}

Source: Compiled from ADB (2020a, 2020b), IMF (2020), OECD (2018), WEF (2020), World Bank (2020a, 2020b, 2020c), and WTO (2020) Note: n.a refers to unavailable. Balance of trade, exports and imports in services for India in 2005 refers to 2008 and balance of trade, export and import in services in China and India for 2019 refer to 2018

Table 2 also reveals India's merchandise exports have surged at a CAGR of 17\% that during 2005 to 2010 compared to $23 \%$ in 2000-2005. India's exports of manufactures have remained stable over the period, whereas the share of primary products declined. Following GFC, India's export growth declined sharply to 3.7\% in 2010-2015, whereas it recovered slowly during 2015-2019 at a CAGR of 5.2\%, which is attributed to slowed global demand, domestic infrastructural bottlenecks and policy constraints. Thus, India's export growth has seen swings due to 2008 crisis, the Euro zone crisis and the global slowdown. India's merchandise imports have shown more or less similar trends over the period, due to a reduction in imports of crude oil and petroleum products and gold and silver. In India, merchandise trade balance had declined significantly from $56.2 \%$ in $2001-2005$ to $26.2 \%$ in $2005-2010$ and became negative in 2010-2015. In China, merchandise trade balance remained lower compared to India and became negative in 2015-2019. Over the period, China's trade balance remained higher than India, which reflects the robustness of services sector in India compared to China.

In 2018, China was the world's largest economy (in purchasing power parity terms), the second-largest economy at market prices (Mason \& Shetty, 2019) and the largest exporter of goods and services compared to the $14^{\text {th }}$ largest 
in 1995 (Constantinescu et al., 2018). However, China's growth has slowed to 6.5\% in 2018 and its import growth continued to outpace export growth, thereby contributed to declining in current account surplus (World Bank, 2019). In recent years, China pursued looser macroeconomic policies to counter the potential economic impact of trade disputes with the US.

Trade performance of China and India in terms of Balance of Payment (BoP) and Balance of Trade (BoT) is presented in Table 3. China's BoP on current account had surged from 2000 to 2015 followed by a steep decline in 2018 and exports remained significantly higher than imports over the period. In China, BoT in goods had surged rapidly from 2000 to 2015, but declined in 2018, while BoT in services remained negative and overall BoT increased strongly up to 2010 and slowed afterwards to reach US\$ 18.9 billion in 2018. In contrast, India's BoP on current account remained negative throughout, while exports and imports have sustained over the period and balance of trade in goods and services respectively remained negative and surged significantly, while overall balance of trade had increased steadily and stood at US\$ 43.6 billion in 2017.

Table 3. Balance of payment and trade in China and India (US\$ billion)

\begin{tabular}{|c|c|c|c|c|c|c|c|c|c|c|c|c|}
\hline \multirow{3}{*}{ Year } & \multicolumn{6}{|c|}{ China } & \multicolumn{6}{|c|}{ India } \\
\hline & \multicolumn{3}{|c|}{ Balance of payment } & \multicolumn{3}{|c|}{ Balance of trade } & \multicolumn{3}{|c|}{ Balance of payment } & \multicolumn{3}{|c|}{ Balance of trade } \\
\hline & $\begin{array}{l}\text { Current } \\
\text { account }\end{array}$ & Exports & Imports & Goods & Services & Overall & $\begin{array}{l}\text { Current } \\
\text { account }\end{array}$ & Exports & Imports & Goods & Services & Overall \\
\hline 2000 & 20.4 & 218.1 & 188.1 & 29.9 & -1.1 & 10.5 & -2.6 & 45.4 & -57.9 & -12.4 & 1.7 & 5.8 \\
\hline 2005 & 132.4 & 689.0 & 564.7 & 124.3 & -0.2 & 250.6 & -9.9 & 105.1 & -157.0 & -51.9 & 23.2 & 15.0 \\
\hline 2010 & 237.8 & 1478.1 & 1239.9 & 238.1 & -15.0 & 471.7 & -47.9 & 256.3 & 383.5 & -127.1 & 44.1 & 13.0 \\
\hline 2015 & 304.1 & 2142.7 & 1566.5 & 576.2 & -218.3 & 117.8 & -22.1 & 266.4 & 396.4 & -130.1 & 69.7 & 17.9 \\
\hline 2018 & 49.1 & 2417.4 & 2022.3 & 395.2 & -292.2 & 18.9 & -57.2 & 337.2 & 517.5 & -180.3 & 81.9 & 43.6 \\
\hline \multicolumn{13}{|c|}{ CAGR (\%) } \\
\hline $2000-2005$ & 45.3 & 25.8 & 24.6 & 32.9 & -34.7 & 88.6 & 30.6 & 18.3 & 22.1 & 33.1 & 68.6 & 20.9 \\
\hline $2005-2010$ & 12.4 & 16.5 & 17.0 & 13.9 & 105.3 & 13.5 & 37.1 & 19.5 & - & 19.6 & 13.7 & -2.8 \\
\hline 2010-2015 & 5.0 & 7.7 & 4.8 & 19.3 & 70.8 & -29.3 & -14.3 & 0.8 & 0.7 & 0.5 & 9.6 & 6.6 \\
\hline 2015-2018 & -45.5 & 4.1 & 8.9 & -11.8 & 10.2 & -36.7 & 37.3 & 8.2 & 9.3 & 11.5 & 5.5 & 56.1 \\
\hline 2000-2018 & 5.0 & 14.3 & 14.1 & 15.4 & 36.3 & 3.3 & 18.7 & 11.8 & - & 16.0 & 24.0 & 12.6 \\
\hline
\end{tabular}

Source: Compiled from ADB (2020a, 2020b), IMF (2020), OECD (2018), WEF (2020), World Bank (2020a, 2020b, 2020c), and WTO (2020) Note: Balance of trade in services for China in 2005 refers to 2004 and overall balance of trade for China in 2015 refers to 2014 and overall balance of trade for India in 2018 refers to 2017

China was the fifth largest exporter of services and the second-largest importer of commercial services, with global share of imports at 9.2\% in 2017 (World Bank, 2019). India had been a net exporter of services and its trade balance in services has modestly increased. India's share in global services exports has increased modestly in recent years. Export of software services constitute nearly half of the total service exports of India, which have been consistently rising over past several years except a marginal decline in 2016-2017 (GoI, 2018).

Table 4 reveals that bilateral trade balance between China and India has surged twenty-one times between 2001 and 2005 and stood at US\$56.9 billion in 2019. With trade liberalization, scenario changed significantly with a sizable surge in India's bilateral imports. In 2009, China emerged as India's leading bilateral trade partners with large exports to India, thereby causing serious bilateral trade imbalances between two economies. In 2012, India's bilateral trade deficit with China reached an unsustainable level of US\$ 39.1 billion (IMF, 2013). Currently, the bilateral trade between China and India is larger than the combined bilateral trade of Germany, the UK and Japan. During the last decade, increasing 
bilateral trade imbalance between China and India has not been rectified, which remained unmanageable even during recent recession. Trade deficit has increased exponentially over the period and may not be sustainable in near future. Uncovered trade gap grew sharply and trade deficit has started increasing since 2002, which increased rapidly during 2004-2007, when the world economy was booming.

Table 4. Bilateral trade between China and India (US\$ billion)

\begin{tabular}{|c|c|c|c|c|c|c|}
\hline Year & $\begin{array}{l}\text { Between China } \\
\text { and India }\end{array}$ & $\begin{array}{l}\text { China's exports } \\
\text { to India }\end{array}$ & $\begin{array}{l}\text { China's imports } \\
\text { from India }\end{array}$ & $\begin{array}{c}\text { Between } \\
\text { India and China }\end{array}$ & $\begin{array}{l}\text { India's exports } \\
\text { to China }\end{array}$ & $\begin{array}{l}\text { India's imports } \\
\text { from China }\end{array}$ \\
\hline 2001 & 0.2 & 1.8 & 1.7 & -0.9 & 0.9 & 1.8 \\
\hline 2005 & 4.3 & 8.9 & 9.7 & -2.9 & 7.2 & 10.1 \\
\hline 2010 & 20.0 & 40.9 & 20.8 & -23.8 & 17.4 & 41.2 \\
\hline 2015 & 44.8 & 58.3 & 13.4 & -52.1 & 9.5 & 61.6 \\
\hline 2019 & 56.9 & 74.9 & 17.9 & -51.1 & 17.3 & 68.4 \\
\hline \multicolumn{7}{|c|}{ CAGR (\%) } \\
\hline $2001-2005$ & 84.7 & 49.1 & 54.5 & 34.0 & 68.2 & 53.9 \\
\hline $2005-2010$ & 46.8 & 35.7 & 16.5 & 52.3 & 19.3 & 32.5 \\
\hline $2010-2015$ & 17.5 & 7.3 & -8.4 & 16.9 & -11.4 & 8.4 \\
\hline $2015-2019$ & 6.1 & 6.5 & 7.5 & -0.5 & 16.2 & 2.6 \\
\hline 2001-2019 & 36.9 & 23.0 & 14.0 & 25.1 & 17.8 & 22.4 \\
\hline
\end{tabular}

Source: Compiled from ADB (2020a, 2020b), IMF (2020), OECD (2018), WEF (2020), World Bank (2020a, 2020b, 2020c), and WTO (2020) Note: Trade balance between China and India for 2005 refers to 2006

In 2012, bilateral trade deficit between China and India was estimated at US\$ 39.2 billion, but with declining growth rate since 2006, however, bilateral trade deficit has been increasing significantly except in 2009. In China, current account surplus in 2017 remained similar to 2016, but expected to increase slightly due to high demand by economies along the Belt and Road during 2018-2022. In India, falling trade deficit has reduced current account deficit during 2013 to 2016 and current account deficit is expected to widen during 2018-2022, due to renewed import of general merchandise and non-monetary gold in 2017 (OECD, 2018). Over the period, China has emerged as India's largest trading partner, but bilateral trade gap of India is also increasing with its overall trade gap with rest of the world, which contributes to overall trade imbalance of India and poses a policy challenge to sustain trade between two countries along with narrowing the existing bilateral trade gap, which can be addressed effectively by India's technology-intensive exports to China.

\section{Conclusion and policy implications}

There is a growing coordination between China and India in multilateral trade negotiations. However, there are immense opportunities to boost further the trade in both countries through mutual cooperation and collaboration to accelerate the growth process. China and India are leading economies having substantial gap between actual trade and trade potential. Therefore, both countries have a long way to go to reap full trade potential, for which concerted and sustained efforts are needed on the part of both Asian giants. Intra-industry trade in intermediate manufactured goods has considerable scope for boosting trade between China and India. Both countries have identifiable differences in export specialization in terms of natural resource endowments, skills, and policy. For instance, India's exports are heavily concentrated in cotton textiles and garments, whereas China specialize in manmade fibers based textiles and garments, which has immense trade potential. 
Both countries are required to remove existing trade barriers and constraints to reap full trade potential focusing on customs rules and procedures, standards, certification and regulatory practices, non-tariff barriers, and rules of origin. Mutual consensus on customs valuation and guidelines to facilitate uniform documentation across ports are needed to increase China-India trade. Trade documents related to standards, certification, regulatory practices, rules, and regulations need to in English as per international practice. Technical and agricultural standards are required to be streamlined to boost China-India trade. Tariff-quota on agricultural products and non-tariff barriers on automotive parts and components are required to be eliminated for trade promotion and smoother economic cooperation between the two countries.

India has a comparative advantage in the English language skill in service industries, whereas China has an advantage in labour-intensive manufacturing for export sectors. India has comparatively more skilled human talent in engineering, automobiles, chemicals, and pharmaceuticals, whereas, China has more skilled human resources in consumer electronics, telecommunications, and other consumer durables. At the same time, both countries have talented manpower in mathematics and science skills. Therefore, these differences in skills call for cooperation between two Asian titans to reap full potentials of manpower skills.

Despite high degree of openness, both countries experienced a small deceleration in growth in recent years. Therefore, free trade and sustained reforms are the best options for China and India to return to sustainable growth rates. Divergence between imports and exports may have long-term implications for China's current account balance. Divergent growth paths along with numerous commonalities have been experienced in both countries. Besides differences in their drivers of growth, similar development strategies have been used during global buoyancy or recession. China is facing increasing challenges in using ELG strategy, whereas in India, this strategy is still a credible development strategy. During recent crisis and low external demand, both China and India have pursued domestic demand-based economic policies.

The pattern of integration into global economy widely differs between China and India and bilateral trade linkages have become stronger over the period. India can reap the full benefits of economic reforms, if performance of manufacturing remained high. At the external front, India has huge potential to utilize the win-win opportunities of collaboration with China in the capital, technology, trade and investment for manufacturing and infrastructure development, which would strengthen economic relations further. Therefore, there is need to address the barriers to sustained economic cooperation between two countries by eliminating mistrust and increasing confidence.

China and India should opt for sustained cooperation in global trade by entering into traditional trade negotiations as equal partners, building their trust in rules-based negotiations, and negotiating agenda collectively to replicate their growth and trade priorities. Traditional trade cooperation should be strengthened and deepen to sustain trade openness by addressing the outstanding barriers to trade in goods and services. Cooperation between should be widened beyond trade policy by focusing on taxes, regulation, and infrastructure. Cooperation between China and India in GVCs should reduce policy spillovers and realize robust growth.

\section{Conflict of interests}

The author declares no conflict of interest.

\section{References}

Abu Al-Foul, B. (2004). Testing the export-led growth hypothesis: Evidence from Jordan. Applied Economics Letters, 11(6), 393-396.

ADB (2020a). Asian Development Outlook 2020, Supplement June. Asian Development Bank. Manila.

ADB (2020b). Asian Development Outlook 2020. Asian Development Bank. Manila.

Afxentiou, P. C., \& Serletis, A. (1991). Exports and GNP Causality in the industrial countries: 1950-1985. Kyklos, 44(2), 167-179.

Ahmad, F., Draz, M. U., \& Yang, S. (2018). Causality nexus of exports, FDI and economic growth of the ASEAN5 economies: Evidence from panel data analysis. Journal of International Trade \& Economic Development, 27(6), 
685-700.

Al-Yousif, K. (1997). Exports and economic growth: Some empirical evidence from the Arab Gulf countries. Applied Economics, 29(6), 693-697.

Amirkhalkhali, S., \& Dar, A. A. (1995). A varying-coefficients model of export expansion, factor accumulation and economic growth: Evidence from cross-country, time series data. Economic Modelling, 12, 435-441.

Awokuse, T. O. (2005). Exports, economic growth and causality in Korea. Applied Economics Letters, 12(11), 693-696.

Balassa, B. (1978). Exports and economic growth: Further evidence. Journal of Development Economics, 5(2), 181189.

Balassa, B. (1980). The process of industrial development and alternative development strategies. Princeton Essays in International Finance, 141. Princeton, NJ: Princeton University, Department of Economics.

Balassa, B. (1985). Exports, policy choices, and economic growth in developing countries after the 1973 oil shock. Journal of Development Economics, 4(1), 23-35.

Baliamoune-Lutz, M. (2011). Growth by destination (where you export matters): Trade with China and growth in African countries. African Development Review, 23(2), 202-218.

Bans-Akutey, A., \& Tiimub, B. M. (2021). Identifying research gaps in scholarly work: A review. Academia Letters, Article 3237.

Barro, R. J., \& Sala-i-Martin, X. (1995). Economic Growth. New York: McGraw-Hill.

Begum, S., \& Shamsuddin, A. F. M. (1998). Exports and economic growth in Bangladesh. Journal of Development Studies, 35(1), 89-114.

Bhagwati, J. N. (1978). Anatomy and Consequences of Exchange Control Regimes. Cambridge: Ballinger.

Bhagwati, J. N. (1988). Export-promoting trade strategies: Issues and evidence. The World Bank Research Observer, $3(1), 27-58$.

Bhagwati, J. N., \& Srinivasan, T. N. (1975). Foreign trade regimes and economic development: India. National Bureau of Economic Research, New York.

Boltho, A. (1996). Was Japanese growth export-led? Oxford Economic Papers, 48(3), 415-432.

Bruton, H. J. (1989). Import substitution as a development strategy. In H. B. Chenery \& T. N. Srinivasan (Eds.), Handbook of Development Economics (Vol. II, pp. 1601-1644). Amsterdam: North Holland.

Burney, N. A. (1996). Exports and economic growth: Evidence from cross country analysis. Applied Economics Letters, 3, 369-373.

Constantinescu, C., Mattoo, A., \& Ruta, M. (2018). Trade in developing East Asia: How it has changed and why it matters. Background Paper for A Resurgent East Asia: Navigating a Changing World. World Bank. Washington, DC.

Catão, L. A. V. (1998). Mexico and export-led growth: The Porfirian period revisited. Cambridge Journal of Economics, 22(1), 59-78.

Chang, C. C., \& Mendy, M. (2012). Economic growth and openness in Africa: What is the empirical relationship? Applied Economics Letters, 19(18), 1903-1907.

Chenery, H. B., \& Strout, A. M. (1966). Foreign assistance and economic development. American Economic Review, 56(4), 679-733.

Chow, P. C. Y. (1987). Causality between export growth and industrial development: Empirical evidence from the NICs. Journal of Development Economics, 26(1), 55-63.

De Gregorio, J. (1992). Economic growth in Latin America. Journal of Development Economics, 39, 59-84.

Denzin, N. K. (1978). The Research Act: A Theoretical Introduction to Sociological Methods. New York: McGrawHill.

Dhananjayan, R. S., \& Devi, N. S. (1997). Exports and economic growth: A study of select nations in Asia and Europe during 1980-81 to 1993-94. Indian Journal of Applied Economics, 6, 41-63.

Dinç, D. T., \& Gökmen, A. (2019). Export-led economic growth and the case of Brazil: An empirical research. Journal of Transnational Management, 24(2), 122-141.

Dodaro, S. (1993). Exports and growth: A reconsideration of causality. Journal of Developing Areas, 27, $227-244$.

Dollar, D. (1992). Outward-oriented developing economies really do grow more rapidly: Evidence from 95 LDCs, 1976-85. Economic Development and Cultural Change, 40, 523-544.

Dollar, D., \& Kraay, A. (2004). Trade, growth, and poverty. The Economic Journal, 114(493), F22-F49.

Edwards, S. (1998). Openness, productivity and growth: What do we really know? The Economic Journal, 108(447), 383-398.

El-Elbeydi, K. R. M., Hamuda, A. M., \& Gazda, V. (2010). The relationship between export and economic growth in 
Libya Arab Jamahiriya. Theoretical and Applied Economics, 17(1), 69-76.

Emery, R. F. (1967). The relation of exports and economic growth. Kyklos, 20(2), 470-486.

Emery, R. F. (1968). The relation of exports and economic growth: A reply. Kyklos, 21(4), 757-760.

Feder, G. (1983). On exports and economic growth. Journal of Development Economics, 12(2), 59-73.

Findlay, C., \& Watson, A. (1996). Economic growth and trade dependency in China. 96/5, Adelaide: Chinese Economies Research Centre, University of Adelaide.

Gbaiye, O. G., Ogundipe, A., Osabuohien, E., Olugbire, O., Adeniran, O. A., Bolaji-Olutunji, K. A., Awodele, O. A., \& Aduradola, O. (2013). Agricultural exports and economic growth in Nigeria (1980-2010). Journal of Economics and Sustainable Development, 4(16), 1-5.

GoI (2018). Economic Survey 2017-18. Ministry of Finance, Department of Economic Affairs, Government of India. New Delhi.

Gonçalves, R., \& Richtering, J. (1987). Intercountry comparison of export performance and output growth. The Developing Economies, 25, 3-18.

Greenaway, D., Morgan, W., \& Wright, P. (2002). Trade liberalization and growth in developing countries. Journal of Development Economics, 67, 229-244.

Greenaway, D., \& Sapsford, D. (1994). Exports, growth and liberalization: An evaluation. Journal of Policy Modeling, 16(2), 165-186.

Grossman, G., \& Helpman, E. (1991). Trade knowledge spillovers and growth. European Economic Review, 35, $517-$ 526.

Harrison, A. E. (1996). Openness and growth: A time series cross-country analysis for developing countries. Journal of Development Economics, 48, 419-447.

Heller, P. S., \& Porter, R. C. (1978). Exports and growth: An empirical re-investigation. Journal of Development Economics, 5(2), 191-193.

Helleiner, G. K. (1986). Outward orientation, import instability and African economic growth: An empirical investigation. In S. Lall \& F. Stewart (Eds.), Theory and Reality in Development: Essays in Honour of Paul Streeton. Hong Kong: MacMillan.

Henriques, I., \& Sadorsky, P. (1996). Export-led growth or growth-driven exports? The Canadian Case. Canadian Journal of Economics, 29(3), 541-555.

Herzer, D., Nowak-Lehmann, F. D., \& Siliverstovs, B. (2006). Export-led growth in Chile: Assessing the role of export composition in productivity growth. The Developing Economies, 44(3), 306-328.

Howitt, P., \& Aghion, P. (1998). Capital accumulation and innovation as complementary factors in long-run growth. Journal of Economic Growth, 3(2), 111-130.

IMF (2020). Direction of Trade Statistics. International Monetary Fund. Washington DC.

IMF (2013). Direction of Trade Statistics. International Monetary Fund. Washington DC.

Islam, M. N. (1998). Exports expansion and economic growth: Testing for Cointegration and Causality. Applied Economics, 30(3), 415-425.

Jin, J. C. (2000). Openness and growth: An interpretation of empirical evidence from East Asian Countries. Journal of International Trade and Economic Development, 9(1), 5-17.

Jouini, J. (2015). Linkage between international trade and economic growth in GCC countries: Empirical evidence from PMG estimation approach. The Journal of International Trade \& Economic Development, 24, 341-372.

Jung, S. W., \& Marshall, P. J. (1985). Exports, growth and causality in developing countries. Journal of Development Economics, 18, 1-12.

Kalaitzi, A. S., \& Chamberlain, T. W. (2020). Merchandise exports and economic growth: Multivariate time series analysis for the United Arab Emirates. Journal of Applied Economics, 23(1), 163-182.

Kalaitzi, A. S., \& Cleeve, E. (2018). Export-led growth in the UAE: Multivariate causality between primary exports, manufactured exports and economic growth. Eurasian Business Review, 8(3), 341-365.

Kaushik, K. K., \& Klein, K. K. (2008). Export growth, export instability, investment and economic growth in India: A time series analysis. Journal of Developing Areas, 41(2), 155-170.

Kavoussi, R. M. (1984). Export expansion and economic growth: Further empirical evidence. Journal of Development Economics, 14(1/2), 241-250.

Keesing, D. B. (1967). Outward-looking policies and economic development. The Economic Journal, 77(306), 303-320.

Khan, A. H., \& Saqib, N. (1993). Exports and economic growth: The Pakistan experience. International Economic Journal, 7(3), 53-64.

Kormendi, R. C., \& Meguire, P. G. (1985). Macroeconomic determinants of growth: Cross country evidence. Journal of 
Monetary Economics, 16, 141-163.

Korstjens, I., \& Moser, A. (2018). Series: Practical guidance to qualitative research. Part 4: Trustworthiness and publishing. European Journal of General Practice, 24(1), 120-124.

Kravis, I. B. (1970). Trade as a handmaiden of growth: Similarities between the nineteenth and twentieth centuries. Economic Journal, 80(320), 850-872.

Krueger, A. O. (1978). Foreign Trade Regimes and Economic Development: Liberalization Attempts and Consequences. Cambridge, MA: Ballinger.

Krueger, A. O. (1985). The experience and lessons of Asia super-exporters. In V. Corbo, A. O. Krueger \& F. Ossa (Eds.), Export-oriented Development Strategies: The Success of Five Newly Industrialized Countries. London: Westview Press.

Kwan, A. C. C., \& Cotsomitis, J. A. (1991). Economic growth and the expanding export sector: China 1952-1985. International Economic Journal, 5(1), 105-116.

Levine, R., \& Renelt, D. (1992). A sensitivity analysis of cross-country growth regressions. American Economic Review, $82(4), 942-963$.

Love, J. (1994). Engines of growth: The export and government sectors. World Economy, 17, 203-218.

Love, J., \& Chandra, R. (2004). Testing export-led growth in India, Pakistan and Sri Lanka using a multivariate framework. Manchester School, 72(4), 483-496.

Mallick, S. S. (1994). Exports and economic growth. Journal of Indian School of Political Economy, 3(6), 505-515.

Marjit, S., \& Ray, M. (2017). Export profitability, competition and technology. International Review of Economics \& Finance, 47, 35-45.

Mason, A. D., \& Shetty, S. (2019). A resurgent East Asia: Navigating a changing world. World Bank Group. Washington, DC.

Mbaku, J. M. (1989). Export growth and economic performance in developing countries: Further evidence from Africa. Journal of Economic Development, 14, 127-142.

Michaely, M. (1977). Exports and growth: An empirical investigation. Journal of Development Economics, 4(1), 49-53.

Mishra, P. K. (2011). Exports and economic growth: Indian scene. SCMS Journal of Indian Management, 8(2), 17-26.

Moschos, D. (1989). Export expansion, growth and the level of economic development: An empirical analysis. Journal of Development Economics, 30(1), 93-102.

Narayan, P. K., Narayan, S., Prasad, B. C., \& Prasad, A. (2007). Export-led growth hypothesis: Evidence from Papua New Guinea and Fiji. Journal of Economic Studies, 34(4), 341-351.

Ncube, P., \& Cheteni, P. (2015). The impact of the BRICS alliance on South Africa economic growth: A VECM approach. MPRA Paper No. 73488. Munich.

Nidugala, G. K. (2001). Exports and economic growth in India: An empirical investigation. Indian Economic Journal, 47(3), 67-78.

Noble, N., \& Heale, R. (2019). Triangulation in research, with examples. BMJ Journals, 22(3), 67-68.

O'Donoghue, T., \& Punch, K. (2003). Qualitative Educational Research in Action: Doing and Reflecting. Routledge.

OECD (2018). Economic Outlook for Southeast Asia, China and India 2018: Fostering Growth through Digitalisation. Organization for Economic Cooperation and Development. Paris.

Panas, E., \& Vamvoukas, G. (2002). Further evidence on the export-led growth hypothesis. Applied Economics Letters, 9(11), 731-735.

Papanek, G. F. (1973). Aid, foreign private investment, savings, and growth in less developed countries. Journal of Political Economy, 81, 120-130.

Pomponio, X. Z. (1996). A causality analysis of growth and export performance. Atlantic Economic Journal, 24(2), 168176.

Ram, R. (1985). Exports and economic growth: Some additional evidence. Economic Development and Cultural Change, 33, 415-425.

Ram, R. (1987). Exports and economic growth in developing countries: Evidence from time-series and cross-section data. Economic Development and Cultural Change, 36(1), 51-63.

Ray, S. (2011). A causality analysis on the empirical nexus between export and economic growth: Evidence from India. International Affairs and Global Strategy, 1, 24-38.

Riezman, R. G., Summers, P. M., \& Whiteman, C. H. (1996). The engine of growth or its handmaiden? A time series assessment of export-led growth. Empirical Economics, 21, 77-113.

Rodriguez, F., \& Rodrik, D. (2000). Trade policy and economic growth: A skeptic's guide to the cross-national evidence. NBER Macroeconomics Annual, 15, 261-325. 
Romer, P. M. (1986). Increasing returns and long-run growth. Journal of Political Economy, 95(5), 1002-1037.

Sachs, J. D., \& Warner, A. M. (1995). Natural resource abundance and economic growth. National Bureau of Economic Research Working Paper, No. 5398. Cambridge, MA.

Sachs, J. D., Warner, A. M., Aslund, A., \& Fischer, S. (1995). Economic reform and the process of global integration. Brookings Papers on Economic Activity, 1995(1), 1-118.

Sala-i-Martin, X. (1996). Regional cohesion: Evidence and theories of regional growth and convergence. European Economic Review, 40(6), 1325-1352.

Sala-i-Martin, X., Doppelhofer, G., \& Miller, R. I. (2004). Determinants of long-term growth: A Bayesian Averaging of Classical Estimates (BACE) approach. American Economic Review, 94(4), 813-835.

Sampath, R. K., \& Anwar, M. S. (2000). Exports and economic growth. The Indian Economic Journal, 47(3), 79-88.

Sephton, P. S. (1989). Causality between export growth and industrial development: empirical evidence from the NICs: A Comment. Journal of Development Economics, 31(2), 413-415.

Serletis, A. (1992). Export growth and Canadian economic development. Journal of Development Economics, 38(1), 133-145.

Serven, A. K. (1968). The relation of exports and economic growth: Comment. Kyklos, 21(3), 546-548.

Shan, J., \& Sun, F. (1998). On the export-led growth hypothesis: The econometric evidence from China. Applied Economics, 30, 1055-1065.

Sharma, A., \& Panagiotidis, T. (2004). An analysis of exports and growth in India: Cointegration and causality evidence (1971-2001). Review of Development Economics, 9(2), 232-248.

Shirazi, N. S., \& Manap, T. A. A. (2005). Exports-led growth hypothesis. The Developing Economies, 43(4), $472-488$.

Siliverstovs, B., \& Herzer, D. (2006). Export-led growth hypothesis: Evidence for Chile. Applied Economics Letters, 13(5), 319-324.

Sprout, R. V. A., \& Weaver, J. H. (1993). Exports and economic growth in a simultaneous equations model. Journal of Developing Areas, 27, 289-306.

Sun, H., Awan, R. U., Nawaz, M. A., Mohsin, M., Rasheed, A. K., \& Iqbal, N. (2021). Assessing the socio-economic viability of solar commercialization and electrification in south Asian countries. Environment, Development and Sustainability: A Multidisciplinary Approach to the Theory and Practice of Sustainable Development, 23(7), 98759897.

Sun, H., Edziah, B. K., Kporsu, A. K., Sarkodie, S. A., \& Taghizadeh-Hesary, F. (2021). Energy efficiency: The role of technological innovation and knowledge spillover. Technological Forecasting \& Social Change, 167, 120659.

Syron, R. F., \& Walsh, B. M. (1968). The relation of exports and economic growth: A note. Kyklos, 21(3), $541-545$.

Tang, T. C. (2006). New evidence on export expansion, economic growth and causality in China. Applied Economics Letters, 13(12), 801-803.

Tyler, W. G. (1981). Growth and export expansion in developing countries: Some empirical Evidence. Journal of Development Economics, 9(1), 121-130.

Vernon, R. (1966). International investment and international trade in the product cycle. The Quarterly Journal of Economics, 80(2), 190-207.

Vohra, R. (2001). Export and economic growth: Further time series evidence from less developed countries. International Advances in Economic Research, 7(3), 345-350.

Wacziarg, R., \& Welch, K. H. (2008). Trade liberalization and growth: New evidence. The World Bank Economic Review, 22(2), 187-231.

WEF (2020). Global Competitiveness Report 2020. World Economic Forum. Switzerland.

Wha-Lee, J. (1993). International trade distortions and long-run economic growth. IMF Staff Papers, 40(2), $299-328$.

World Bank (2020a). World Development Indicators. World Bank Group. Washington, DC.

World Bank (2020b). East Asia and Pacific Economic Update: East Asia and Pacific in the Time of COVID-19. World Bank. Washington, DC.

World Bank (2020c). Global Economic Prospects. June. World Bank. Washington, DC.

World Bank (2019). Global Economic Prospects. World Bank Group. Washington, DC.

World Bank (2018). China Economic Update: Investing in High-Quality Growth. World Bank Group. Washington, DC.

World Bank (2017). East Asia Pacific Economic Update: Balancing Act. World Bank Group. Washington, DC.

World Bank (2011). World Development Indicators. World Bank Group. Washington, DC.

World Bank (1993). The East Asian Miracle: Economic Growth and Public Policy, Oxford: Oxford University Press.

WTO (2018). World Trade Statistical Review 2018. World Trade Organization. Geneva.

WTO (2020). World Trade Statistical Review 2020. World Trade Organization. Geneva. 
Yaghmaian, B., \& Ghorashi, R. (1995). Export performance and economic development: An empirical analysis. The American Economist, 39, 37-45.

Yanikkaya, H. (2003). Trade openness and economic growth: A cross-country empirical investigation. Journal of Development Economics, 72(1), 57-89.

Zahonogo, P. (2016). Trade and economic growth in developing countries: Evidence from sub-Saharan Africa. Journal of African Trade, 3(1-2), 41-56. 